\title{
Neighborhood effects and women's agency regarding poverty and patriarchy in a Turkish slum
}

\section{Tahire Erman}

Department of Political Science, Bilkent University, Ankara 06800, Turkey; e-mail: tahire@bilkent.edu.tr

\section{Süheyla Türkyılmaz}

Esfor Security Consulting, Bağdattioğlu plaza Kozyatağl, Istanbul 34742, Turkey; e-mail: turkyilmaz.suheyla@gmail.com

Received 22 July 2006, in revised form 30 October 2006; published online 20 May 2008

\begin{abstract}
This paper aims to understand the interplay between the neighborhood (spatial) effects of poverty, ethnicity, kin, and patriarchy, and women's agency in the context of an inner-city slum in Ankara, the capital of Turkey. It is based on a field study that focuses on the experiences of women residents - that is, rural migrants known for their dependency on neighborhood spaces - and their grown-up daughters who were raised in the city. The neighborhood context-namely, the social and physical isolation of the site, the limited access to urban institutions, and the growing risk of crime-has a negative impact on women's lives, restraining but not determining women's agency. Women's struggle for agency in this context is contingent on other factors, including whether they live in ethnic clusters and whether their husbands are working, as well as urban experience and individual biography.
\end{abstract}

\section{Introduction}

This paper investigates neighborhood effects as structural constraints in a slum in the Turkish context, and also pays attention to women's agency. The concept 'neighborhood effects' is used in the paper to refer to those conditions and characteristics of the locality that distinguish it from other localities. The assumption in 'neighborhood effects' studies is as follows: "There exist geographically specific social and economic factors that exert influences on individuals' behaviors. Put another way, where one lives (alternatively labelled neighborhood, census tract, block, project, or ghetto) influences one's behavior" (Teitler, 1996, page 7). Neighborhood effects research has gained momentum in the 1990s; it doubled between the mid1990s and the year 2000 (Sampson and Morenoff, 2002). The increasing attention paid to space and its role in human action has made the concept popular particularly in geography, sociology, and economics. The fact that neighborhood effects studies can bear significant policy implications, furthermore, has increased their importance. Health professionals were drawn to them (eg Leventhal and Brooks, 2004; Pachter et al, 2006; Subramanian et al, 2006). Urban poverty researchers are another group interested in neighborhood effects (eg Brooks-Gunn et al, 1997; Harding, 2005; Holloway and Mulherin, 2004). Wilson's (1987) study of the ghetto, with a focus on how the neighborhood conditions help to reproduce ghetto disadvantages, has been a seminal work in urban poverty.

Neighborhood effects studies, by their focus on structural factors, disregard human agency. They often use datasets available from government offices and private institutions and look at how the specific characteristics of the neighborhood (eg institutional resources, measures of poverty, peer effects, neighborhood ties) affect human behavior (eg individual health outcomes, poverty, criminal behavior, problem behaviors such as delinquency, violence, depression) (Dietz, 2002; Sampson and Morenoff, 2002). Identifying causation is the major goal, and statistical models are developed for analysis 
(eg Subramanian, 2004). This paper, on the other hand, diverges from mainstream neighborhood effects research in two related ways: its reliance on the qualitative research paradigm and its aim to incorporate human agency. Without dismissing the contributions made by quantitative neighborhood effects research, it brings an ethnographic approach that can benefit social scientists and policymakers alike. Our aim is to understand the dynamics of the locality in a holistic way and to grasp what is going on in the locality in all its complexity. We pay attention both to the locality and to its residents in terms of their mutual influence.

We have chosen a neighborhood of concentrated disadvantage and a growing risk of crime to study neighborhood effects, and we have focused on its women residents - namely, rural migrant women - in order to understand human agency in the neighborhood context. This is, firstly, because 'pockets of crime' are emerging in the neighborhoods of the urban poor. Today, urban poverty along with urban violence and crime are increasing in the world. Criminal activities, especially illegal drug dealing, have flourished in many squatter settlements of Latin American cities, and the settlements have come under the control of criminal gangs and drug traffickers (Perlman, 2004; Rolnik, 2001). Crime also reigns in African cities crowded with slums, and to a lesser degree in Asia (UNHSP, 2003). In Turkey organized crime and drug trafficking have been creeping into squatter areas recently, posing a threat to their social order (Bozkulak, 2004); intraneighborhood violence is often observed in these areas (Erman and Eken, 2004). Unemployment in big cities has risen, ${ }^{(1)}$ increasing the likelihood of criminal activities. Steady employment and job security are being replaced by irregular jobs without insurance and health benefits, making families live under precarious economic conditions.

And, secondly, this is because in the Turkish context rural migrant women are spatially bound to their neighborhood spaces (Erman, 1996). The fact that rural migrant women spend much of their time in the proximate spaces of their home environment because of traditional patriarchy that defines women in relation to the private sphere and acts to keep women close to home makes migrant women locally dependent. Furthermore, as rural migrants from the same home town cluster in the same neighborhood in the city as the result of chain migration, creating ethnic enclaves, they reinforce traditional patriarchy and act as a social control mechanism over women (Erman, 2001; Güneş-Ayata, 1990/91). Consequently, women stay inside the neighborhood, socializing with their neighbors in the semipublic/semiprivate spaces around their homes - that is, in courtyards and alleyways or in front of their houses, spaces which enable social interaction. They establish social ties and create networks of support and cooperation (Erman, 1998). In this way, they become the main actors shaping neighborhood life. Thus, in general, it is important to understand women's experiences in slums since they live their lives in double disadvantage (that is, as being poor and as women), and some recent studies have investigated this issue (eg Ramana, 2002). And, in this particular context, it is important to find out how worsening local conditions affect women's lives, and if they can do anything to change the situation. Stated differently, we ask to what extent the neighborhood context determines women's lives.

Recently, some attention has been paid to human agency in poor people's interaction with their disadvantageous housing environments (eg Gotham, 2003). Moving beyond the idea that causal linkages exist between neighborhood context (geographic space), individual behavior, and social outcomes, these studies draw attention to poor 
people's active struggle to make a place for themselves under the conditions of poverty, prejudice, and exclusion. In line with these studies, this paper aims to reveal poor people's struggle for agency in a slum, and, by bringing a gender perspective, it furthermore aims to show how women, along with poverty and exclusion, cope with patriarchy and domestic violence. It investigates the issue of women's agency under very disadvantageous spatial and social conditions, and asks whether women can hold some agency to get out of the negative conditions that impinge on their lives; if so, whether this agency carries some potential to improve the locality and to pull it out of slum conditions; and what factors promote or defer women from exerting agency.

In the paper we present quotations by respondents to give voices to these highly disadvantaged women, and we provide detailed descriptions of the locality to bring ethnographic richness to the paper and to give readers a sense of embeddedness in the research site.

\section{Field study}

The paper draws on ethnographic data and interviews. ${ }^{(2)}$ A field study was carried out between September 2002 and January 2004 in Çandarl. Ankara. The introduction to the research site was through two routes - namely, the Community Center (Toplum Merkezi) and Türkyılmaz's former neighbor's mother living in Çandarlı, who acted as the key informant. During the visits to the neighborhood, field notes were taken, and content analysis of them was carried out. In addition, in-depth interviews were conducted with thirty women and their daughters above the age of 14 years. Two different sets of questions were prepared for women and their daughters. Respondents were interviewed in their houses or courtyards. In some Kurdish families, when the women did not understand the questions, their children translated them. During the interviews, observations of the women and their environment were recorded. Following the initial interviews, the families were visited again, sometimes upon the request of the women, who wanted to talk to Türkyılmaz, usually asking for help. Türkyılmaz offered help when possible, especially targeting women's agency. For example, she took the daughter, who had a genetic illness, to the hospital, and provided information and support to her mother so that she could take her daughter to the doctor by herself; and a lawyer friend of hers provided information to a woman, who had started thinking of divorcing her alcoholic husband, about the procedure.

Furthermore, we interviewed the staff of the community center and the health clinic. We also talked to the muhtar (elected head of the neighborhood). We visited the neighborhood in 2005 and 2006, during which we contacted several former respondents and observed the changes in their lives and in the neighborhood. The research was not extended to the neighborhood further up in the hills where criminal activities were more common because of safety concerns. Secondary data were obtained from government offices. We visited the mayor and interviewed him about the neighborhood and the larger district. In addition, we reviewed the news about the neighborhood that appeared in daily journals.

In the field study, except for two cases, the typical family emerged as follows: the woman is illiterate. Because of traditional beliefs that girls should stay at home and should not mix with boys, they were not sent to school. In their childhood, instead, they worked at home, shouldering housekeeping responsibilities when their mothers were working in the fields; some also worked in the fields themselves. They married at a young age when they were 14 or 15 years old. Some lived with their in-laws for

(2) The data were largely collected for a master's thesis (Türky1lmaz, 2004). 
several years, usually being exposed to violence both by their in-laws and by their husbands, and then migrated to the city; and others moved directly to the city upon their marriage. They chose this neighborhood because of cheap rents and because their people were living there, and they have been living here since then. The exceptions are two women who grew up in the city. They ended up here as the result of falling in love with and marrying men disapproved of by their families.

More than half of the respondents were tenants (eighteen out of thirty), and among the tenants there were those who moved to the city many years ago. Many had lived all their lives in the city. The families usually had many children. While four to five children was the norm, one family had only two children, and two families had seven children. Many women complained about domestic violence (sixteen). In one family the woman was beaten both by her husband and by her grown-up son. Several women also complained about their husbands' alcoholism (nine) and adultery (five). Two women had grown-up sons who were in jail: one was because of wounding a man in a fight and the other was related to drug dealing.

Among the thirty women interviewed, ten were Sunni Kurds, two were Armenians, two were Tebers, a subgroup of Alevis-Anatolian Shiites, and the rest were Sunni Turks (sixteen) - eleven of them migrated from villages in Central Anatolia where Ankara is located, three came from other districts of Ankara, and two migrated from the Black Sea region. The majority of respondents migrated between 1970 and 1980 for economic reasons; two families migrated because of a blood feud, and one family migrated because of terrorism in the East.

Most of the husbands were either unemployed (five) or employed in irregular jobs: five were day laborers in constructions and seven worked in low-paid jobs, usually without security, as waiters, cooks, office boys, and cleaning personnel. ${ }^{(3)}$ Kurdish families were relatively advantaged: except for an unemployed husband, they were all in the 'fruits and vegetables open-market trade (4) (pazarcl) (seven). Two husbands were deceased: one of the women lived with her married son who worked in the openmarket, and the other family lived on the widow's pension. In addition, two of the husbands were retired government officers, and one owned a grocery store (he came in 1960). In some families husbands did not bring home money: some would spend their money on gambling, drinking, and/or their lovers; some were de facto husbands, coming home once in a while.

Four of the women worked outside the home, all as cleaning women: two at cleaning companies and two at middle-class homes. Four women made embroidery at home to sell: one of them used to work for a textile company but quit her job because of her husband. The two Armenian women went out to sell trousseau items they produced, making home visits (bohçact), and one woman went to the city center to sell the earrings and necklaces she made at home. On the other hand, the daughters were either students (twelve) - seven in middle school, three in high school, and two in university - or 'house girls' (ev klzl) (seventeen), except one who recently graduated from university. The house girls once attended school, except one who was illiterate.

In the following, we first describe the locality with a focus on its distinguishing characteristics as the basis of neighborhood effects. Then we discuss women's agency, regarding poverty and patriarchy.

(3) This is different from the planned period of $1960-80$, during which many rural migrants were employed in government offices and had social security benefits.

(4) Open-market trade is said to be controlled by the mafia. 


\section{A slummified neighborhood in Ankara: Çandarlı-Altındağ}

In Turkey squatter settlements have been distinct features of the urban scene since the 1950s. They have largely been able to integrate into the city: owing to the availability of large tracks of land inherited from the Ottoman Empire (Keyder, 2000), politicians easily adopted populist policies and tolerated squatter housing to receive squatters' votes. The squatter laws helped the incorporation of squatter areas into the city by bringing infrastructure and services, and the laws that were passed in the mid1980s-by allowing up to four-story apartment buildings to be built on squatter plots-commercialized squatter housing and brought squatter houses into the formal housing market. Thus, squatter housing has become the major means of upward mobility for many rural migrant families, creating a sense of stability and hope for the future (Danielson and Keleş, 1985). This is different from other countries, such as sub-Saharan Africa, where squatter residents live under dire conditions (UNHSP, 2003) and where forced eviction is common (Warah, 2005).

However, not all squatter settlements in Turkey have experienced such transformation. Those built close to the city center on unfavorable sites, such as steep hillsides and riverbeds, deteriorated over the years, turning into slums. Slums, defined as "physically dilapidated and overcrowded... exclusive residential zone for lowest-income groups" (UNHSP, 2003, page 196) and "[urban areas] characterized by overcrowding, deterioration, unsanitary conditions or absence of facilities or amenities, which, because of these conditions or any of them, endanger health, safety or morals of its inhabitants or the community" (Desai and Devadas Pillai, 1990, page 37), have come to characterize these early inner-city squatter settlements. The subject of this paper is such a locality in Ankara, the capital of Turkey. Hidırlıktepe (meaning 'the hill of Hidırlık'), where Çandarlı is located, is the oldest and steepest part of Altında $\breve{g}$, which literally means 'the golden hill', was one of the first squatter settlements established in the late 1940s. Its geographical proximity to the old city center, as well as its sloping hills, played a significant role in making Altındağ the home of early rural migrants to the city: while its proximity to the city center where various jobs were available attracted migrants to the area, its mountainous geography made it undesirable for regular construction, keeping it outside the formal housing market. In the populist policies of the 1950s liberal government, a master plan of the area, including Çandarli, was prepared, and title deeds were distributed, but it was never put into action. Developers were not attracted to Hidirliktepe, because of its unfavorable geographical characteristics, and the state, despite the promises made especially during election times, was unwilling to improve the area. As a result, the locality began to deteriorate over the years. As residents built additional houses in their gardens, added second stories, or built extensions, the area became denser and more crowded, and, as some squatter houses were transferred over to the next generation when the first residents passed away, it produced a very complicated tenure, making it difficult to apply the master plan. Of Ankara's eight districts, Altındağ is the poorest district, and has the highest number of large households and the highest crime rates. It is rated as the second district in terms of illiteracy and unemployment rates (Turkish State Institute of Statistics, 2004, data prepared upon personal application). By the end of the 1990s, the percentage of tenants reached $80 \%$ (Altında g Municipality, 1998). In contrast to its promising name, the 'golden hill', which implies that the district is full of opportunities, it has become the place of those who lack opportunities to make a life for themselves in the city. 


\section{Distinguishing characteristics of the locality: the basis of neighborhood effects}

The houses in Çandarlı are built densely; mostly, several houses are built around a small courtyard with a shared toilet. The entrances of the houses are usually used as the kitchen space. The way the houses are formed and the labyrinth-like alleyways give a strong sense of irregularity to the neighborhood. Inside the neighborhood, the streets are usually so narrow that two persons can hardly walk side by side. Many of the houses are in very poor condition. As the director of the community center put it,

"These are houses in ruins (viran evler), they are not gecekondus [squatter houses]." The houses are heated by cheap coal which is forbidden by the municipality, and it causes much air pollution. Tap water, which is not for drinking and may be contaminated, is used for drinking. The neighborhood's garbage is dumped at a site close to its entrance, and is collected once a week by the municipality. It occasionally grows into a rubbish heap, and in the summer it stinks. This gives the image of a locality abandoned by the state.

The fact that Çandarlı lies on steep slopes makes access to the area rather difficult. This is especially true when there is a heavy fall of snow since the municipality does not allocate any services to clean the snow off the roads. Although there are buses that run through Çandarl, the bus schedule is not usually followed, especially in the winter. There is no public transportation to that part of the area up in the hills.

There is a primary school but the quality of education is poor because, among other things, it is difficult to keep a permanent teaching staff: teachers do not want to come to this locality. There is also a mosque and a health clinic. A community center was established in 1993 in Altındağ by the Directorate of Social Services and Children's Protection to serve the larger area, including Çandarlı. In the center of the neighborhood there are a couple of grocery stores, two coffeehouses located close to the school, and a clubhouse of an association across from the school, which is run as a coffeehouse. There is gambling in the clubhouse, although it is against the law. It has been closed by the police several times but it reopened. It is highly probable that the proximity of these buildings to the school has negative influences on students.

There are 112 houses in Çandarlı. But, as the health clinic personnel say, the number of people living in the houses changes a great deal because people come and go, especially gypsies. Recently, the neighborhood has been attracting the poorest families, who rent deteriorating houses. Moreover, drug users have begun to occupy vacant houses in poor condition. Many of the first residents moved to other districts as they improved their conditions, and a few of them remained. They live in the houses they own which are close to the center.

Although the first residents were mostly Sunni Turks - the majority group in Turkey - in later years the neighborhood became the site of various minority ethnic groups who have a bad reputation in the mainstream society. There are many Kurdish people who live in their big families: some moved here from their villages for economic reasons and ended up controlling the open-market trade, and several came later to seek employment in this trade when they had to leave their villages because of terrorism. The state's armed struggle against Kurdish uprising, during which both sides suffered heavy casualties, has led to a negative labelling of Kurdish migrants in big cities. However, in this locality the fact that Kurdish men are relatively better off compared with some very poor residents places them above other minority ethnic groups. There are also Tebers: while Alevis (Anatolian Shiites) as a broad category have a problematic relationship with the Sunni Muslim community going back to the Ottoman times, Tebers, a subgroup of Alevis, bear a strong stigma in this neighborhood because of the way they earn their living - that is, by begging. Most Tebers live further up in the hills. There are several Armenian families. They reject this identity in public, 
although in their private circles they speak Armenian. These families are clustered in one long street. And up in the hills live gypsies. Many come in groups in the winter; the cheap rents draw them here. They do not register themselves and tend not to send their children to school. They live on collecting wastepaper. And they go away in the summer when they can live in the tents they set up. They frequently become the target of complaints by the authorities because of their uncommitted presence in the neighborhood. The initial residents, who make claims to the locality ('This is our neighborhood'), complain about the growing number of people from minority ethnic groups and try to maintain a distance from them. For example, a woman said, "Those from Haymana and Erzurum [they are both Kurdish], neither do I talk to them, nor do I let my children. The gypsies are the worst. Be they live away from us."

The locality is socially fragmented, which is reflected in its spatial configuration. Residents live in their own groups, forming their enclaves. Spatial clustering of migrants from the same village or region in the same locality in the city is a common characteristic of squatter settlements in Turkish cities. Some degree of animosity may exist among the groups, especially if there are ethnic and sectarian differences (GüneşAyata, 1990/91). What makes Çandarlı different is the uneasy, and sometimes violent, coexistence of the groups. Being the poorest of the poor-having hit the bottom - and hence having nothing to lose, makes residents open to 'anything', as the community center's director put it; it has created tendencies towards illegality. Easy money attracts local men to drug dealing, especially the youth, many of whom are unemployed. Empty alcohol bottles and glue tins as the signs of alcohol and drug abuse have come to make their presence felt in the locality. Recently, drugs are being sold in the school's courtyard. The competition over the illegal drug turf occasionally bursts into violent confrontations. Confrontation is a general tendency that dominates the neighborhood. The following statement by one of the respondents summarizes this tendency to fight:

"The gypsies fight a lot. They especially cannot get along with the Kurds. They

fight very badly. Stones, sticks, whatever they have, they use. Women fight because of children, men fight because of cars parked in their parking spaces; they fight because of this and that. They always find a reason to fight."(5)

The police take a passive role in the fight against drug dealing. Some residents say that the police ally with drug gangs and profit from such activities, and others say that they are intimidated because of the threat of retaliation:

"There will always be a time for the police to take off their uniforms and be a part of the crowd; then they should watch out if they have not cooperated with the gangs." The periphery of the neighborhood, up in the hills, remains largely out of police control.

Thus, in addition to the relative physical isolation of the locality, there is its social isolation: the reputation of the locality as the site of criminals, drug dealers, villains, as well as the Kurds and the gypsies is keeping people away from the area. Furthermore, illegal activities, which they observe in their everyday lives, disturb many residents and weaken their attachment and commitment to the locality. This is different from other squatter settlements in which residents care about their locality and invest their labor to improve it. In the interviews, many respondents expressed their desire to

(5) Such an event was observed during the field study: when there was a 'problem' between the Kurdish and gypsy groups (different explanations of the 'problem' exist), the gypsies, who came down from the hills where they lived, set fire to the Kurdish grocery store, next to which the grocer kept bottled gas to sell. There was a big explosion, which burnt many houses behind the store, all resided in by Kurdish families. In the end, the police succeeded in making the Kurds move out of the neighborhood in order to put an end to the confrontation between the two groups, which could easily turn into a 'blood feud'. 
move out to a safe neighborhood and their inability to do it. They feel they are stuck in this neighborhood. A woman (45 years old), who moved to Çandarlı in 1980, said,

"Here is full of esrarcı [opium smokers/sellers)]. Illegal activities take place all the time. Just before you came, the police organized a raid on the house next door: they were printing fake dollar bills. I ask you, is it safe here? The poor, like me, who do not have the money to live somewhere else, stay."

We conclude that this locality, which was once one of the early squatter settlements in the city, has turned into a slum over the years. Its congested and unsanitary environment, decaying housing stock, poor quality health and educational facilities, very substandard infrastructure and services, as well as its very poor and, in some cases, ethnically stigmatized residents, who are fragmented among themselves leading to social disorganization, characterize the locality as a slum. Moreover, the neighborhood has become the site of illegality and crime. As the state failed to bring services to the neighborhood (in the muhtar's own words, "The state has left the neighborhood to its fate") and as the houses deteriorated over the years, as those who improved their conditions moved out, renting their rundown houses to the very poor or just abandoning them, drug dealers have moved in, forming their networks of illegality. Under these neighborhood conditions, local women's experiences are shaped; these experiences are presented below.

\section{Local women and their experiences in the locality}

Although poverty is a defining characteristic of squatter settlements in general, severe poverty causing a precarious existence puts its stamp on the everyday experiences of residents in this locality. Many families struggle for daily survival. Those families in the open-market trade do not experience severe poverty, although they do not have regular incomes to rely on. On the other hand, many of those families in which the husband is unemployed or absent live on the verge of starving. Those whose neighbors work in the open-market have access to leftover vegetables and fruits. Some collect waste materials to sell for recycling. Although most of the families have television sets (some of them are very old, and black and white), women do not usually turn them on during the day to save electricity costs. This is different from other squatter settlements where daytime television programs have become the only entertainment and the main means of contact of rural migrant women with the outside world.

It may well be expected that severe poverty would push women to seek employment. However, in the field study only a few women worked outside the home. Conservative values and traditions, legitimized by religion ("Our religion does not permit women's employment") and reinforced when living within a kin network, tend to keep women at home. Husbands, as well as women's own families, do not approve of their working outside the home. A woman (41 years old) complained as follows:

"Our people [ie relatives and fellow villagers in the city, both men and women] hold negative views of women. My husband never let me work. He does not care if we are hungry or in the cold. So we keep waiting for what he might bring home."

The stigma placed on working women continues, to a large extent, in the case of the younger generation, affecting their lives adversely and preventing them from contributing to their families. Usually, daughters are not sent to school beyond primary school (recently, eight years of schooling has become mandatory); after they leave their education, they spend time at home, waiting to get married.

This is true for squatter settlements in general where patriarchal values act against women working outside the home, and women can easily be labelled as losing family honor (namus) if they start working (Erman et al, 2002). In this neighborhood, women are further discouraged from seeking employment outside the home because of their 
concern both for their own safety and for the safety of their children left behind. Streets, which are safe places in typical Turkish squatter settlements, are not safe here any more (one of the first residents mentioned how she used to keep her door unlocked because the neighborhood was very safe then). A woman (38 years old) talked about this as follows:

"It is very dangerous here. When it gets dark, neither do I go out nor let my children out. They fire guns, kill people, bad things happen."

Daughters complained that the neighborhood was both conservative and dangerous; they said women had no rights and no freedom. The streets of the neighborhood are becoming male spaces, in contrast to typical squatter settlements where women can safely and appropriately spend time outside their dwellings, socializing with their neighbors in the spaces in front of their houses ["squatter environments as female spaces" (Erman, 1998)]. And this is eroding women's networks. While during the daytime some women still carry out housework (eg washing the dishes) in front of their houses in the narrow, labyrinth-like alleyways because their houses are too small, they, nevertheless, tend to limit their presence to inner streets, staying away from the public spaces of the neighborhood. After dark, the neighborhood falls prey to male gang members. ${ }^{(6)}$

In squatter settlements in Turkey, traditional patriarchy prevails, and wife beating is not uncommon. This may be challenged as women start working outside the home when economic conditions dictate, and as families spend more time in the city, becoming familiar with urban values that disapprove of domestic violence (Erman, 2001). In Çandarlı, on the other hand, the situation is different. A culture of illegality and violence is emerging that feeds 'violent patriarchy'. The type of behavior that is defined as shameful by the mainstream society, such as serving time in jail, may be something to be proud of here; it may be regarded as a sign of male toughness. Young men may steal cars, drive them proudly in the neighborhood, and leave them on the street when the car runs out of fuel. The social construction of masculinity as men's use of physical force, which legitimizes domestic violence, is not merely an urban phenomenon that emerges in the context of neighborhoods of illegality and crime, but is also fed by the remnants of traditional patriarchy of the village. This culture of violence is shaping most adversely the younger generation, both girls and boys. A female student broke the windows of a doctor's car when the doctor did not comply with her request for a sickness report for her school absence. A young woman was pulled by her hair when she wanted to help her younger sister who was being beaten by some boys when she talked back to their verbal harassment, and her mother could do nothing but watch.

The neighborhood as the site of the poorest people shapes local women's experiences. Poverty relief in cash and kind (coal, food) distributed by government agencies, as in other neighborhoods of the urban poor, produces competition among local women, who may report each other to the authorities to disqualify them from receiving the aid. In this locality, however, such competition may have ethnic nuances. For example, an Armenian family was reported by their neighbors to have their 'green card' (access to free health care in state hospitals) cancelled because they had a car (it was an old car and used rarely). In addition to the competition over scarce resources, poverty itself tends to erode neighborly relations. Although there is some cooperation among several neighbors since they need each other (for example, to make large quantities of bread for the winter) - this is a common practice among the women in squatter settlements-extreme poverty is isolating women when they are too poor to carry out neighborly obligations. A woman (38 years old) said, 
“I don't visit my neighbors. If I visit them, they will also come to visit me. I want to offer them something. But I need money to do it. So neither do I go, nor do I want them to visit me."

In some houses the only furniture is a mattress to sleep on, making neighborly visits impossible.

In brief, women's everyday experiences are formed under the conditions of severe poverty, violent patriarchy, and a growing risk of crime. In this geography of danger, poverty, isolation, and patriarchy, to what extent can we talk about women's agency? As humans have varied agency in coping with their living conditions, what characteristics enable women to fight patriarchy and poverty? What about women's grown-up daughters? Do they differ from their mothers in terms of their agency regarding poverty and patriarchy? What can we do to increase women's agency? And what can we do to prevent the locality from turning into a site of criminality and social abandonment? In the following we address these questions.

\section{Women's agency regarding poverty and patriarchy}

Some women take on an active role in coping with poverty, especially if husbands do not assume responsibility for their families: they try to borrow money from their neighbors; they buy bread from the local grocery store on credit (a woman made an agreement with the grocery to buy stale bread at a cheaper price); they prepare food, such as noodles and tarhana (dried yoghurt and dough for soup), for winter provisions. Some walk to Hacı Bayram (a religious center in the vicinity of the neighborhood) in groups early in the morning and wait in line to get bread distributed to the poor, and many make their own bread. Some try hard to support their families by making needlework: unfortunately their products largely remain inside the neighborhood. Their customers would mostly be the early residents who are not as poor as the other residents, and, if they are very lucky, they can reach middle-class people through their neighbors' connections (eg through a neighbor working as a cleaning woman for a middle-class family or through an early resident whose children moved out to better sections of the city). Women also take on an active role to persuade authorities that they are the ones who deserve poor relief distributed by government agencies.

Although taking initiatives to fight poverty and patriarchy may be separate issues, they are interrelated in the Turkish context. Women's engagement in outside work, although it does not necessarily bring women's empowerment (Erman et al, 2002; Salway, 2005), becomes the means of bringing the family out of severe poverty in many cases. However, patriarchal cultural values tend to prevent it. In patriarchal family arrangements, as a rule, men take on the role of the breadwinner and women become housewives. In many families in this neighborhood, on the other hand, this division of gender roles in the family is disrupted. Many husbands are unemployed or irregularly employed, or they do not bring home money. And, when men fail to fulfil the role of a proper husband, this opens up the door for women to challenge their violently subordinated existence. However, many women cannot use this opportunity ('pessimistic cases'). They cannot divorce their husbands because they are dependent, more so socially and psychologically than economically, and are concerned about the stigma attached to divorced women by their social circle. The violence they are subject to and the severe poverty they live in produce physical and psychological health problems: many women complained about their illnesses, such as gynaecological problems, migraine headaches, insomnia, rheumatism, and depression. A sense of helplessness dominates their lives. They are usually too worn out, and lack confidence, awareness, and contacts to challenge patriarchy. Moreover, many have troublesome pasts: some are orphans; some were married to 'undesirable' men 
(old, very poor, disabled); some were disowned by their families when they ran away with their present husbands.

Despite all this, some of these women have started questioning their husbands' domination as they have lost trust in them, but they do not know how to get out of this situation. At this point some intervention-for example, the community center-can help women to break out of their subordination and physical abuse. Interestingly, some women even in this group of 'pessimistic cases', although very few, may gain the will to struggle to come out of their oppressive lives, while others remain powerless. The issue of what specific factors play a role deserves further investigation. The following is the story of such a woman who struggled for her agency. She lost her patience when, in addition to her poverty-stricken life full of incidents of domestic violence, her husband took a lover. She is a Kurdish woman in her thirties. She married her neighbor's son in the village when she was 15 years old. They moved to Ankara when her husband found a job in the open-market. In the city the husband had a lover. He would spend several days with her, and the rest with his family. The woman talked about it as follows:

"When he came home, he would beat me as if I were a dog. He would drag me by my hair. I thought I would die. My children developed psychological problems. I was fed up with this. One day I cut at its roots my hair reaching down to my waist so that he could not grab me by my hair any more. Then I burnt it because I didn't want to see it, I didn't want to remember."

This woman participated in the activities of the community center, and she played the role of a battered woman in the drama class. The worst conditions may open the door for women's emancipation when there is outside support.

The daughters in the 'pessimistic' families tend to see marrying at a very young age as an escape from the unbearable conditions in their families, which reproduces their poverty and subordination in their adult lives. Married daughters, who have witnessed their mothers' sufferings, may find it difficult to raise their own families. The two married daughters in the field study returned to their mothers' houses when they faced problems in their marriages. Some suffer from depression. In one family the father was an alcoholic. He would drink and beat his wife and his daughter for no reason. The daughter was prone to depression. She would stay in her room all day long. She hated her life and the neighborhood, and believed that nothing could change it. Suicide attempts are not rare. A young woman, who has a 1-year-old baby and is now living with her mother after her mother-in-law threw her out, attempted to commit suicide several times. She showed us the marks of the cuts on her wrists.

These daughters, who, unlike their mothers, grew up in the city, and who, again unlike their mothers, have received a higher level of education, are more aware of women's rights; they have come to realize that living under the violent domination of men is not a natural way of existence. A daughter (15 years old), who is a primary school graduate, expressed her opinion as follows:

"A woman should be aware of her rights. If she does, she can overcome any difficulty. But usually women are exposed to violence; men dominate. Women can resist this by learning about their rights but they are kept ignorant."

But they do not know how to change their lives. Again some intervention can help them to find a way out of their situation.

In contrast to the 'pessimistic cases' in which women fail to exert agency, in several other families women managed to work outside the home despite the initial objection of their husbands ('optimistic cases'). They are the ones who grew up in the city, including the two women who ended up in this locality when their marriages were disapproved of by their families. Their husbands are either unemployed or irregularly employed, and they live outside the network of kin and fellow villagers. Thus, urban 
experience, when combined with the inability of the husband to act as the provider and the relative absence of social control by kin, has some liberating effects. The women fought their own fights against their husbands. Occasionally, it was an open resistance

"My husband beat me, tried to change my mind, but I did not give in", but mostly women used tactics to overcome their husbands' objection

"My husband never wanted me to work. But I told my neighbors that I was looking for a job. One day they told me that a family was looking for a cleaning woman, and I started working. I did not say anything to my husband until I was sure that it was going fine. When he saw money coming, he did not object any more."

Working outside the home has empowered the women. They expressed positive views of themselves and of women in general. They said,

"Women have the power to achieve anything. Look at me. My husband beat me to prevent me from working, but I resisted. I can do anything if I want to."

“As long as God gives me good health, I can make my bread out of stone." Women working outside the home contributed to their families by extending the social contacts beyond the neighborhood. This is important in the case of this locality which is isolated from the city to a large extent. For example, a woman (40 years old) who worked as a cleaning woman for a middle-class family not only earned money to support her family, but also through this middle-class family was able to find a scholarship for her daughter, who was a university student in a small city.

By the money they make, the women tend to support their daughters' education. It is in these families that we find the few daughters who are in college (three): one daughter is a recent university graduate, and two others are going to university in small cities. These daughters are the few fortunate ones who can develop the necessary qualities to be able to stand against their destiny determined by poverty and patriarchy. They are hopeful for their future. For example, a daughter (18 years old) whose mother worked for a cleaning company and whose father was unemployed said,

"Our conditions are not good but I believe that they will improve. When I graduate and find a good job, I will help my family".

Another daughter (21 years old) whose mother worked as a cleaning woman and whose father worked in a bakery said,

"I will graduate in two years. Then we will have a better life". Both girls appreciate very much their mothers' financial support.

In brief, these women's ability to get out of the neighborhood and to engage in money-earning activities has allowed them to assume agency to break out of patriarchy and poverty. ${ }^{(7)}$ But, by doing so, they have violated local norms and values. They are able to overcome their potential bad reputation in the locality by isolating themselves from the locality. They want to move out as soon as they find the opportunity. ${ }^{(8)}$ The growing risk of crime strengthens this tendency, hindering any commitment to the locality.

In sharp contrast to those families in which the potential to challenge patriarchy has emerged when husbands lost their instrumental role of bringing home money, in some other families patriarchy remains untouched. They are mostly those with Kurdish

(7) In the case of the trousseau sellers, who also go out of the neighbourhood, their economic activity is regarded by their group as women's traditional responsibility, and although it has improved the families' economic conditions it has failed to pull the women out of the patriarchy embedded in the locality.

(8) In 2006 a family moved out of the neighborhood immediately the daughter graduated from university. 
origins who live in big groups of kin and who are in the open-market trade. Men bring home some money, although it may fluctuate based on sales, and they never allow women to work outside the home, both their wives and their daughters. The women in these families, in general, accept their situation as natural. For example, a Kurdish woman (38 years old), who moved to Ankara in 1980 from a village in Eastern Turkey, said,

"I have never worked. In our customs women do not work outside the home. It is both a shame and a sin; it is against our religion. Husbands work, bring home food, and we eat."

Only in one such family, in which the husband was unemployed (he was the only one unemployed among the Kurdish men), and there were seven children, the wife (45 years old) complained about the attitude of her husband as follows:

"It would be so good if my daughter could start working. But I know that, damn him, my husband will never allow it. We are born to suffer, nothing changes this." These women stay inside the neighborhood, and they do not have contacts outside of their social circle. This increases their social isolation: many barely speak Turkish or do not speak Turkish at all, including those who migrated to Ankara many years ago (in the 1970s and early 1980s). As they have been living in Çandarlı since their migration to Ankara, and they have not been outside the locality, they are not aware of a different way of life than their very patriarchal family arrangements, and they do not question their subordination in the family. Here it should be noted that it is not Kurdishness per se that explains the situation but the fact that husbands bring home some money, and conservative migrant families from the same place of origin are clustered together, forming a social network through which traditional values are reproduced and control over women is maintained. This reproduction of patriarchy can also be observed in other squatter settlements. What makes this neighborhood different is its extreme form because of its considerable isolation.

The daughters in these families are not allowed to work outside the home. The ideal future defined for them is to get married to someone chosen by their parents, and they are expected to be housewives, bearing and rearing children. Because of the patriarchal culture prevalent in their social circle, probably their husbands will also dominate in the family. So, as several daughters put it, "The mother's bad fate is inherited by the daughter". A daughter, who left middle school, complained:

"Look at my mother. I will suffer like her. One day I will get married by an arranged

marriage and leave my family. Then I will suffer in the rest of my life."

These daughters, like other daughters in the research, are more conscious of their rights than their mothers. But they cannot put their ideas into action. A primary school graduate (22 years old) said,

"Educated women find jobs; they can achieve anything. But we are not like them. Look, my mother is powerless, she suffers. I will end up like her because I am not educated."

A primary school dropout (17 years old) said,

"I would like to have a good job. I would like to earn money and meet new people.

But a good education is a must. My family would never let me work. In our customs women do not work. My father, my brothers would kill me if I did."

Based on the information provided above, we can argue that whether husbands are working and bringing home some money, and hence whether they are fulfilling their gender role expectations as breadwinners, whether women live in ethnic clusters in which patriarchal values are reproduced and social control over women is maintained, women's individual biographies (eg traumatic childhood and forced marriages), and urban experience act as important factors that promote or defer women from exerting agency. And this locality as the isolated site of rural migrants and ethnic 
clusters, and of the most unfortunate, produces those conditions that hold back women's agency. Intervention is needed so that women can develop agency to break out of the cycle of poverty, patriarchy, and domestic violence. This intervention can be through the community center.

\section{The community center as a means of intervention at the household level}

The community center can make a difference in the lives of local people. Its personnel are mainly women, including the director. The center aims to empower women-for example, by offering drama courses in which women play the role of battered housewives. As the director stated in our interview, its goals are to bring women an awareness about their rights and to create self-esteem. It organizes sewing courses for women, not to teach them traditional gender roles but to increase their self-confidence by giving them the opportunity to make money of their own by selling their products. However, the center lacks adequate resources and personnel, ${ }^{(9)}$ and fails to reach women in different parts of the district. The women in Çandarlı are disadvantaged because of the poor access to the neighbourhood and because of its bad reputation. In the field study, there were women who had not heard about the center. But, once the center reaches a woman, she can mobilize other women living in close proximity. The women, who are violently abused by their husbands, may learn quickly to take advantage of this institution for their salvation. In one case, the wife of an alcoholic husband, who was repeatedly beaten by him, ran to the center to seek help. And, in another case, it was the center that reached the victim, the eldest daughter of a very poor family with seven children. Her mother did not speak Turkish, her father was an alcoholic and unemployed, and her elder brother was in jail. Although she grew up in the city, she was illiterate. The center's staff went to persuade her father to give her permission to attend literacy courses at the center. So the daughter, as she developed contacts with the center, began to take a leading role in her family; she was able to gain access to poverty aid in the municipality.

Several NGOs carried out projects in this neighborhood, such as Çağdaş Yaşamı Destekleme Derneği (the Association for the Support of Contemporary Life) and the Ankara Lions Club. But when their projects, which are usually defined on a yearly basis, were over, they moved out to other neighborhoods, leaving this neighborhood on its own. In brief, their projects as confirmed by the school principal, are very limited in their capacity to change the neighborhood and the lives of the local women for the better. The 'pessimistic cases' can turn into promising cases only by long-term, reliable, sustainable intervention.

As we have seen, not many women hold agency to improve their lives. And the few women who have developed initiatives to break out of poverty and patriarchy tend to disassociate themselves from their neighbors [Wacquant's (1999) 'strategies of distancing', ie 'I am not one of them'], and hence by not acting as role models for the rest they do not have a positive influence in the locality. This makes significant the issue of what can be done to save the locality from its present conditions of poverty, isolation, and illegality. In the following section, one such intervention, which is increasingly used by the municipalities, is discussed.

\section{Intervention at the neighborhood level: urban transformation projects}

As the result of the decentralization policies in Turkey in the last decade, local governments have increased their discretionary power and revenues, and they have started developing various projects for the city. Urban transformation projects have appeared

${ }^{(9)}$ Some were transferred here when they conflicted with the political party in office; hence, it was like being sent into exile. 
in the agenda of local governments. In his election campaign, the mayor of Altındağ addressed the problem of slummification in 'old Altındağ', talking about a project of 5000 housing units that would displace 801 squatter houses; 8 -10-story apartment blocks, along with terraced houses, would be built, housing 20000 persons. Following it, the Aktaş/Atilla urban transformation project has been put into action in a section of Altındağ located down the hills of Hidırlıktepe. In its initial stage, which started in 1997, the relocation of 330 houses was targeted. However, today the outcome is several apartment blocks built on two sides of an asphalted road. In a survey that measured the satisfaction levels of residents in the project, $50 \%$ of the respondents were dissatisfied with their new residential environment: $70 \%$ expressed problems with living in high-rise apartment blocks with no gardens, and 30\% said that they missed their former lifestyles in squatter houses (Dündar, 2005). This may be especially true in the case of women who spend much of their time outdoors with their neighbors in the semipublic/semiprivate spaces in squatter areas, and who become confined to apartments in transformation projects. Displacement is the outcome of transformation projects, and it affects the most vulnerable groups, such as women, children, and the elderly. Moreover, physical improvement of an area may actually facilitate the appropriation of some of its spaces by drug gangs (Penglase, 2002). This is especially true in high-rise housing environments where open spaces are a 'no man's land'.

In conclusion, physical intervention through urban transformation projects is not the solution. These projects ignore women's experiences. Participatory projects in which women's involvement is targeted, which can help develop women's agency in the process, should be promoted. NGOs, especially women's NGOs, should be involved in such transformations. The formation of women's courts by NGOs as an intervention strategy, in which women's violent subordination by their husbands and in-laws is publicly challenged, is a striking example (Magar, 2003). Women's NGOs in Turkey should develop their culturally responsive strategies to become effective in the society. As is evident in the field study, the weakest link in the vicious circle of poverty and patriarchy is those families in which the husband fails to be the breadwinner, and the interventions of NGOs in these families would be very significant in breaking out of this vicious circle. Daughters who grew up in the city, furthermore, would be more responsive to the assistance offered by women's NGOs.

\section{Conclusion}

This paper demonstrates that the neighborhood context has a significant impact on women's lives. The social and physical isolation of the site distances women from the opportunities of the city that may bring them awareness and the possibility of challenging patriarchy and poverty, and from institutions, such as the community center, which can help women's empowerment. And the growing risk of crime and violence makes it dangerous to move around, causing problems for women who want to go out to work; and, by turning neighborhood spaces into men's territory, it erodes women's support networks and destroys their local spaces - that is, proximate neighborhood spaces where rural migrant women spend much of their time. Moreover, a culture of illegality is developing, feeding violent patriarchy. All this curbs women's chances to overcome patriarchy and poverty. However, although oppressive conditions structure women's experiences to a large extent, women struggle to escape poverty, and, in some cases, patriarchy. But only a few women can achieve it. Ethnic clustering of conservative families, especially if husbands have the ability to bring home money, reinforces traditional patriarchy, which defines women in relation to home and disapproves of women's outside employment. Thus, women's struggle for agency in this context is contingent on whether they live in ethnic clusters and whether their husbands are working. 
The weakest link in the cycle of poverty and patriarchy appears to be those women whose husbands fail to provide for the family, and the long-term support of women's organizations can help bring women out of their vicious circle.

The 'optimistic cases' are those women who have some urban experience and who live outside the kin group, and hence who can manage to physically leave the neighborhood to work: upon their husbands' failure to provide for the family, they have started working outside the home despite the husbands' initial objections. Their ability to get out of the neighborhood is a significant factor that helped them to assume agency. Their daughters have benefited from it, and are able to attend college through the support of their mothers. However, these women, in their attempts to save their families from poverty, and to escape the bad reputation of working women and the risk of crime in the locality, tend to isolate themselves, and hence lack the potential to improve the neighborhood.

The neighborhood, by drawing the most disadvantaged, and by reproducing their disadvantages due to its sociospatial characteristics, has become the site of extreme forms of poverty and patriarchy. And this requires intervention to change the situation, both social and economic. However, it would be too simplistic to seek to solve the problem by slum clearance as an intervention strategy. Slum clearance and eviction as its outcome are quite common in the 'Third World', especially in sub-Saharan Africa (Obudbo and Mhlanga, 1988). But, in Turkey, populist policies have prevented it to a large extent until now. However, with the change of economic policies from a planned economy to a liberal one, this may be changing, and a harsher attitude towards the urban poor may emerge (Keyder, 2000). The stigma placed on Hidırlıktepe as the place of illegality and crime can easily be used by the local government to justify dislocation, and in the cases of those who do not have title deeds and tenants, eviction would be the outcome. And again women would be the most adversely affected victims of this action. Urban transformation projects as another intervention strategy have increased in number recently, but they have their own problems. Slums in 'Third World cities' deserve our attention more than ever today (Davis, 2006), and a gender perspective will allow us to understand the experiences of the most disadvantaged women and the possible ways to change their lives for the better.

\section{References}

Altındağ Municipality, 1998 Altındağda Dün, Bugün, Yarın [The past, present, and future of Altındağ] (Altındağ Municipality Publication, Ankara)

Bozkulak S, 2004, "Gülsuyu: a neighborhood from gecekondu to varoş", paper presented at the 9th Annual International Cultural Studies Symposium, Ege University, Izmir; the Turkish version of the paper was published in 2005 in Istanbul'da Kentsel Ayrlşma [Urban segregation in Istanbul] Ed. H Kurtuluş (Bağlam Yayınları, Istanbul) pp 239-266

Brooks-Gunn J, Duncan G J, Aber J L, 1997 Neighborhood Poverty: Policy Implications in Studying Neighborhoods, Volume 2 (Russell Sage Foundation, New York)

Danielson M N, Keleş R, 1985 The Politics of Rapid Urbanization (Holmes and Meier, London)

Davis M, 2006 Planet of Slums (Verso, London)

Desai A R, Devadas Pillai S (Eds), 1990 Slums and Urbanization (Sangam Books, Bombay)

Dietz R D, 2002, "The estimation of neighborhood effects in the social sciences: an interdisciplinary approach" Social Science Research 31539 - 575

Dündar Ö, 2005, "Community involvement in local regeneration projects in Turkey", http://www/econturk.org/Turkisheconomy/dundar.pdf

Erman T, 1996, "Women and the housing environment: the experiences of Turkish migrant women in squatter (gecekondu) and apartment housing" Environment and Behavior 28 764-798

Erman T, 1998, "Semi-public/semi-private spaces in the experience of Turkish migrant women in a squatter settlement" Werkstattberichte $2240-50$

Erman T, 2001, "Rural migrants and patriarchy in Turkish cities" International Journal of Urban and Regional Research $25118-133$

Erman T, Eken A, 2004, "The 'Other of the Other' and 'unregulated territories' in the urban periphery; gecekondu violence in the 2000s with a focus on Esenler case, Istanbul" Cities 2157 -68 
Erman T, Kalaycıoğlu S, Rittersberger-Tılıç H, 2002, "Money-earning activities and empowerment experiences of rural migrant women in the city: the case of Turkey" Women's Studies International Forum 25395 - 410

Gotham K F, 2003, "Toward an understanding of the spatiality of urban poverty: the urban poor as spatial actors" International Journal of Urban and Regional Research 27 723-737

Güneş-Ayata A, 1990/91, "Gecekondularda kimlik sorunu, dayanışma örüntüleri ve hemsehrilik" [The identity problem, solidarity networks and hemsehrilik in the gecekondu] Toplum ve Bilim 51/55 $89-101$

Harding D J, 2005 Why Neighborhoods Matter: Structural and Cultural Influences on Adolescents in Poor Communities unpublished PhD dissertation, Department of Sociology, Harvard University, Cambridge MA

Holloway S R, Mulherin S, 2004, "The effect of adolescent neighborhood poverty on adult employment" Journal of Urban Affairs 26427 - 454

Keyder Ç, 2000, "Liberalization from above and the future of the informal sector: land, shelter and informality in the periphery", in Informalization: Process and Structure Eds F Tabak, M A Crichlow (Johns Hopkins University Press, Baltimore, MD) pp 119-132

Leventhal T, Brooks G, 2004, "A randomized study of neighborhood effects on low-income children's educational outcomes" Developmental Psychology 40488 - 507

Magar V, 2003, "Empowerment approaches to gender-based violence: women's courts in Delhi slums" Women's Studies International Forum $26509-523$

Obudbo R A, Mhlanga C C, (Eds), 1988 Slum and Squatter Settlements in sub-Saharan Africa (Praeger, New York)

Pachter L M, Auinger P, Palmer R, Weitzman M, 2006, "Do parenting and the home environment, maternal depression, neighborhood, and chronic poverty affect child behavioral problems differently in different racial - ethnic groups?" Pediatrics 1171329 - 1338

Penglase R B, 2002 To Live Here You Have to Know How to Live: Violence and Everyday Life in a Brazilian Favela unpublished PhD dissertation, Department of Anthropology, Harvard University, Cambridge, MA

Perlman J E, 2004 The Metamorphosis of Marginality in Rio de Janerio (University of Texas, Austin, TX)

Ramana P V L, 2002 Women in Slums: A Study of Women in a Muslim Slum of Visakhapatham (Serials Publishers, New Delhi)

Rolnik R, 2001, "Territorial exclusion and violence: the case of the state of Sao Paulo, Brazil" Geoforum $32471-482$

Salway S, 2005, "Women's employment in urban Bangladesh: a challenge to gender identity?" Development and Change $36317-349$

Sampson R J, Morenoff J, 2002, "Assessing "neighborhood effects": social processes and new directions in research" Annual Review of Sociology $28443-478$

Subramanian S V, 2004, "The relevance of multilevel statistical methods for identifying causal neighborhood effects” Social Science and Medicine 581961 - 1968

Subramanian S V, Kubzansky L, Berkman L, Fay M, Kawachi I, 2006, "Neighborhood effects on the self-rated health of elders: uncovering the importance of structural and service-related neighborhood environments" Journals of Gerontology Series B: Psychological Sciences and Social Sciences $61 \mathrm{~S} 153$ - S160

Teitler J O, 1996 The Impact of Neighborhood Norms on Youth Sexual and Fertility Behavior unpublished PhD dissertation, Department of Sociology, University of Pennsylvania, Philadelphia, PA

Turkish State Institute of Statistics, 2005 Household Workforce Survey of February, March and April, http://www.die.gov.tr/TURKISH/SONIST/ISGUCU/isgucu.html

Türkyılmaz S, 2004, "The experiences of two generations of women in poverty: a case study in Çandarlı, Altındağ in Ankara", unpublished master's thesis, Gender and Women's Studies Programme, Middle East Technical University, Ankara

UNHSP (United Nations Human Settlements Programme), 2003 The Challenge of Slums (Earthscan, London)

Wacquant L, 1999, "Urban marginality in the coming millennium" Urban Studies 361639 - 1648

Warah R, 2005, "Ticking time-bombs: low-income settlements", http://www/unhabitat.org/ mediacentre/documents/sowc/tick.pdf

Wilson W J, 1987 The Truly Disadvantaged: The Inner City, the Underclass, and Public Policy (University of Chicago Press, Chicago, IL) 
Conditions of use. This article may be downloaded from the E\&P website for personal research by members of subscribing organisations. This PDF may not be placed on any website (or other online distribution system) without permission of the publisher. 